\title{
Citrate Blood Cell Fraction
}

National Cancer Institute

\section{Source}

National Cancer Institute. Citrate Blood Cell Fraction. NCI Thesaurus. Code C158461.

The blood cells that are harvested from a cell collection tube containing sodium citrate. 